\title{
Serum levels of sclerostin reflect altered bone microarchitecture in patients with hepatic cirrhosis
}

\author{
Robert Wakolbinger - Christian Muschitz (D) - Jacqueline Wallwitz - Gerd Bodlaj · Xaver Feichtinger · \\ Jakob E. Schanda · Heinrich Resch · Andreas Baierl · Peter Pietschmann
}

Received: 6 September 2019 / Accepted: 9 December 2019 / Published online: 7 January 2020

(C) The Author(s) 2019

\begin{abstract}
Summary
Background Patients with hepatic cirrhosis are at increased risk of bone loss. Recent work on areal bone mineral density has reported contradictory findings. As the assessment of bone microarchitecture is complex, a search was made for correlations with new serum markers of bone turnover. Current data on serum sclerostin levels in patients with increased fracture risk are divergent and to date only one study has examined patients with hepatic cirrhosis. Therefore, the aim of this study was to evaluate serum sclerostin levels and to test for correlations with microarchitecture.

Methods This study was performed in 32 patients with recently diagnosed hepatic cirrhosis and 32 controls. The parameters of bone microarchitecture were
\end{abstract}

Authors contribution Conception and design: RW, CM, GB, XF, JES, HR, AB, PP. Data acquisition, analysis and interpretation: RW, CM, JW, $\mathrm{AB}, \mathrm{PP}$. Article writing and/or critical revision of the manuscript: RW, CM, JW, GB, XF, JES, $\mathrm{HR}, \mathrm{AB}, \mathrm{PP}$

\section{R. Wakolbinger, M.D.}

Department of Physical and Rehabilitation Medicine, Danube Hospital - Social Medical Center East, Academic Teaching Hospital of the Medical University of Vienna, Langobardenstraße 122, 1220 Vienna, Austria

R. Wakolbinger, M.D.

Associate Professor C. Muschitz, M.D. (₫) .

Associate Professor G. Bodlaj, M.D. · X. Feichtinger, M.D.,

Ph.D. · J. E. Schanda, M.D. · Professor H. Resch, M.D.

Medical Department II — The VINFORCE Study

Group, St. Vincent Hospital, Academic Teaching

Hospital of the Medical University of Vienna,

Stumpergasse 13, 1060 Vienna, Austria

christian.muschitz@bhs.at assessed by high-resolution peripheral quantitative computed tomography. Sclerostin was detected via a new ELISA that detects the active receptor interaction site at loop 2 of the sclerostin core region.

Results Sclerostin levels were slightly, but not significantly lower in the patient group, compared to controls. In contrast, patients with alcoholic liver cirrhosis had significantly lower levels than the controls. A significant correlation with areal bone mineral density (BMD) and trabecular microarchitecture was observed in the patient group. However, there was hardly any correlation between sclerostin and bone microarchitecture in the controls.

Conclusion In hepatic cirrhosis, sclerostin is related to altered bone microarchitecture and lower areal BMD.

\section{J. Wallwitz, Ph.D.}

The Antibody Lab, Divischgasse 4, 1210 Vienna, Austria

Division of Pharmacology, Department of Pharmacology, Physiology and Microbiology, Karl Landsteiner University of Health Sciences, Dr.-Karl-Dorrek-Straße 30, 3500 Krems, Austria

X. Feichtinger, M.D., Ph.D. · J. E. Schanda, M.D. AUVA Trauma Center Meidling, Kundratstraße 37, 1120 Vienna, Austria

Professor H. Resch, M.D.

Karl Landsteiner Institute for Gastroenterology and Rheumatology, Stumpergasse 13, 1060 Vienna, Austria

\section{A. Baierl, Ph.D.}

Department of Statistics and Operations

Research, University of Vienna,

Oskar-Morgenstern-Platz 1, 1090 Vienna, Austria

Professor P. Pietschmann, M.D.

Department of Pathophysiology and Allergy Research,

Center for Pathophysiology, Infectiology and Immunology,

Medical University of Vienna, Währinger Gürtel

18-20, 1090 Vienna, Austria 
In alcoholic liver disease, low sclerostin concentrations were seen.

Keywords Alcoholic liver cirrhosis · Trabecular number - Trabecular separation - Sandwich ELISA · Bone mineral density

$\begin{array}{ll}\text { Abbreviations } \\ \text { aBMD } & \text { Areal bone mineral density } \\ \text { ALD } & \text { Alcoholic liver disease } \\ \text { BTM } & \text { Bone turnover markers } \\ \text { CTX } & \text { C-terminal telopeptide of type I collagen } \\ \text { CtPo } & \text { Cortical porosity } \\ \text { CtTh } & \text { Cortical thickness } \\ \text { DXA } & \text { Dual X-ray absorptiometry } \\ \text { ELISA } & \text { Enzyme-linked immunosorbent assay } \\ \text { HR-pQCT } & \text { High resolution peripheral quantitative } \\ & \text { computed tomography } \\ \text { iPTH } & \text { Intact parathyroid hormone } \\ \text { MELD } & \text { Model of end stage liver disease } \\ \text { TbN } & \text { Trabecular number } \\ \text { TbSp } & \text { Trabecular separation } \\ \text { TbTh } & \text { trabecular thickness } \\ \text { TbBV/TV } & \text { Trabecular bone volume fraction }\end{array}$

\section{Introduction}

In patients with hepatic cirrhosis areal bone mineral density (aBMD) is decreased especially at the lumbar spine [1, 2], whereas either decreased [3] or normal values $[1,2,4]$ are observed at the hips. Due to technical limitations, aBMD alone can be insufficient to explain increased fracture risk [5] and bone microarchitecture can provide additional information. We recently investigated bone microarchitecture via high resolution peripheral quantitative computed tomography (HR-pQCT) [3]. As HR-pQCT is technically intensive, expensive and rarely available, serum bone turnover markers (BTMs) should be tested for predictive value. As standard serum markers of bone turnover do not reflect bone microarchitecture in hepatic cirrhosis [3], new markers need to be examined. Sclerostin, a glycoprotein secreted mainly by osteocytes, is a product of the SOST gene. It negatively regulates bone mass via binding to lowdensity lipoprotein receptor-related protein 5 and/or 6 (LRP5/6) and inhibits the Wnt/beta-catenin pathway, thereby decreasing bone formation [6]. To date, the only study investigating serum sclerostin in hepatic cirrhosis reported increased levels [7]. In patients at increased fracture risk, the results are divergent: Whereas some studies reported higher levels in postmenopausal osteoporotic women with fractures [8], diabetics [9] and alcoholics [10], others observed lower levels in geriatric patients with hip fractures [11]. These differences may result from methodological differences (fragments biasing measurements, different antibodies and therefore epitopes recognized, different assay constructions) [12].
A novel sclerostin ELISA was recently developed and launched (BI-20472, Biomedica, Vienna, Austria), which measures bioactive sclerostin by using a monoclonal antibody directed at the LRP5/6 binding region, thereby capturing all circulating sclerostin forms containing the free-receptor binding site. To ensure the reliability of this ELISA, it was validated in depth according to Food and Drug Administration quality standards. Therefore, the aforementioned limitations could be reduced, and the measured analyte specified.

This study shows validation data of the used ELISA and evaluated sclerostin in patients with hepatic cirrhosis, compared to matched healthy controls. The secondary objectives were first to test for correlations of sclerostin with trabecular and cortical bone microarchitecture and second, to examine relationships with serum markers of bone turnover.

\section{Methods}

\section{Subjects}

This study was conducted at the St. Vincent Hospital, an academic teaching hospital of the Medical University of Vienna. After approval by the St. Vincent Hospital ethics committee, patients with recently diagnosed hepatic cirrhosis were screened for eligibility. Written informed consent was obtained from all the patients and controls prior to any procedures. The definition of etiologies of hepatic cirrhosis, inclusion criteria and exclusion criteria have recently been reported [3]. The healthy controls (subject to the same exclusion criteria but no history or laboratory evidence of liver disease) were recruited from active and retired hospital staff.

\section{Serum bone turnover markers}

The BTMs were obtained after overnight fasting between 8 and 10 a.m. at an ISO 9001 certified laboratory. Calcium, alkaline phosphatase, phosphorus, C-terminal telopeptide of type I collagen (CTX), 25$\mathrm{OH}$ vitamin $\mathrm{D}$ and intact parathyroid hormone (iPTH) were determined. Sclerostin serum concentration was determined via ELISA (BI-20472, Biomedica, Vienna, Austria) according to the manufacturer's protocol. In contrast to conventional assays, this ELISA is designed to detect the active receptor interaction site at loop 2 of the sclerostin core region.

\section{Validation of sclerostin ELISA}

Validation experiments of the sclerostin ELISA (BI20472, Biomedica, Vienna, Austria) were performed according to FDA quality guidelines. Specificity was assessed with a commonly used procedure of signal competition with an at least 5-fold surplus of liquid capture antibody and by epitope mapping of linear epitopes of the compiled antibodies with a peptide microarray (Pepperprint $\mathrm{GmbH}$, Heidel- 
berg, Germany). Additionally, the limit of detection (LOD), lower limit of quantification (LLOQ), intra-assay precision, sample parallelism and accuracy were assessed.

The specificity of the ELISA to the protein of interest is one of the most important characteristics. The monoclonal antibody used for capture is directed against the receptor interaction site and is $100 \%$ specific for sclerostin. The polyclonal, horseradish peroxidase-labelled detection antibody has several linear epitopes throughout the molecule determined by a custom-made microarray analysis. For the sandwich ELISA, the competition of endogenous (8 samples) and recombinant sclerostin showed a mean specificity of $100 \%(99-100 \%)$.

\section{Areal bone mineral density}

Dual X-ray absorptiometry (DXA) at the lumbar spine (L1-L4), non-dominant radius (except for previous fractures), total body and hip was assessed. Fractured vertebrae were excluded.

\section{Bone microarchitecture}

The HR-pQCT (XtremeCT, SCANCO Medical, Brütisellen, Switzerland) measurements of the non-dominant (except for previous fracture) distal radius and distal tibia were performed while immobilized in a carbon-fiber cast. Cortical volumetric BMD, trabecular bone volume fraction (TbBV/TV), trabecular number $(\mathrm{TbN})$, trabecular thickness (TbTh), trabecular separation (TbSp), cortical thickness (CtTh) and cortical porosity (CtPo) were measured [3].

\section{Statistics}

Group differences were analyzed using two-sample t-tests. Distributional assumptions were checked visually by quantile-quantile plots. Multiple linear regression models were estimated with sclerostin as an independent variable and measures of BTMs, liverrelated biochemistry and disease severity as dependent variables in separate models. Models with either albumin or adjusted calcium as additional covariate were estimated to investigate whether these parameters explain variation in addition to sclerostin. Model fits were quantified by adjusted $\mathrm{R}^{2}$-values. All tests were two-sided and $p$ values less than 0.05 were considered statistically significant. All statistical analyses were performed with the statistical software R, version 3.50 (R Development Core Team, Vienna, Austria).

\section{Hypothesis}

The hypothesis was to test whether or not serum levels of sclerostin would be altered in patients with hepatic cirrhosis.

\section{Results}

In this study 32 patients (including 12 women) and 32 matched healthy controls (including 12 women) were included. None of the subjects had received a specific treatment for osteoporosis or chronic liver disease. The patients and controls were of similar age (median 62 and 60 years, respectively), 16 patients had alcoholic liver disease (ALD), 8 viral hepatitis, 5 nonalcoholic fatty liver disease, 2 hemochromatosis and 1 autoimmune hepatitis. Age and body mass index did not differ between the patients and controls but alcohol intake was higher in the patients (4 units/day vs. 1 unit/day). None of the patients with ALD were abstinent.

Patients with ALD (63 years) and other etiologies (62 years) were of similar age. The percentages of males were similar for patients with ALD (69\%) and controls $(63 \%)$ but slightly lower for patients with other etiologies (56\%). The Child-Pugh score was similar among the patients with ALD (5) and other etiologies (6).

\section{Sclerostin ELISA validation}

The sensitivity of the assay was $1.9 \mathrm{pmol} / \mathrm{l}$ and the lower limit of quantification was $2.5 \mathrm{pmol} / \mathrm{l}$ (data not shown). The precision of the assay (coefficient of variation) varied from $1 \%$ to $7 \%$. The dilution linearity (also called sample parallelism) should ascertain that the affinity of the antibodies to endogenous sclerostin is similar to the recombinant calibrator. The calculated recovery of $1+1$ and $1+3$ diluted samples was between $86 \%$ and $125 \%$ for serum, EDTA and citrate plasma and therefore within the standard of acceptance. To examine the accuracy, which describes the closeness of determined values to the true concentration of the analyte, recombinant sclerostin with known concentration was added to samples and the percentage of recovery was calculated. Recovery in the lower range was $76-111 \%$ and in the higher range was $82-95 \%$.

\section{Serum sclerostin levels}

The sclerostin levels of all patients were slightly but not significantly $(p=0.18)$ lower $(108 \mathrm{pmol} / \mathrm{l}$, range 91-153 pmol/l) than in the controls (133 pmol/l, 104-181 pmol/l). In ALD, the levels were significantly $(p=0.045)$ reduced to $96 \mathrm{pmol} / \mathrm{l}(66-154 \mathrm{pmol} / \mathrm{l}) \mathrm{com}-$ pared to the controls, whereas patients with other etiologies (120 pmol/l, 107-153 pmol/l) did not significantly differ from either the controls $(p=0.94)$ or from patients with ALD ( $p=0.091)$.

\section{Regression and multivariate analysis}

In the patients, sclerostin correlated significantly with aBMD and microarchitecture. Furthermore, a positive 
original article

Table 1 Linear regression analysis for sclerostin with serum markers of bone turnover, liver-related chemistry and disease severity

\begin{tabular}{|c|c|c|c|c|c|c|c|c|c|c|}
\hline & $\begin{array}{l}\text { Beta } \\
\text { coefficient } \\
\text { patients }\end{array}$ & $\begin{array}{l}\text { Adjusted } \\
\mathrm{R}^{2} \text { pa- } \\
\text { tients }\end{array}$ & $\begin{array}{l}p \text {-value } \\
\text { patients }\end{array}$ & $\begin{array}{l}\text { Adjusted } R^{2} \\
\text { (incl. albumin) } \\
\text { patients }\end{array}$ & $\begin{array}{l}p \text {-value } \\
\text { albumin } \\
\text { patients }\end{array}$ & $\begin{array}{l}\text { Adjusted } \mathrm{R}^{2} \text { (incl. } \\
\text { adjusted calcium) } \\
\text { patients }\end{array}$ & $\begin{array}{l}p \text {-value } \\
\text { adjusted } \\
\text { calcium } \\
\text { patients }\end{array}$ & $\begin{array}{l}\text { Beta } \\
\text { coefficient } \\
\text { controls }\end{array}$ & $\begin{array}{l}\text { Adjusted } \\
\mathrm{R}^{2} \text { con- } \\
\text { trols }\end{array}$ & $\begin{array}{l}p \text {-value } \\
\text { controls }\end{array}$ \\
\hline $\begin{array}{l}\text { Ionized calcium } \\
(\mathrm{mmol} / \mathrm{l})\end{array}$ & -158.68 & -0.027 & 0.516 & -0.078 & 0.815 & -0.055 & 0.497 & 0.000 & -0.040 & 0.706 \\
\hline Calcium (mmol/l) & -66.99 & -0.006 & 0.376 & 0.391 & $<0.001$ & 0.117 & 0.030 & 0.000 & -0.033 & 0.865 \\
\hline $\begin{array}{l}\text { Adjusted calcium } \\
\text { (mmol/l) }\end{array}$ & 22.46 & -0.031 & 0.803 & 0.152 & 0.011 & n.a. & n.a. & 0.000 & -0.034 & 0.882 \\
\hline $\begin{array}{l}\text { Phosphorus } \\
\text { (mmol/l) }\end{array}$ & 58.33 & 0.002 & 0.313 & -0.031 & 0.834 & 0.036 & 0.162 & 0.000 & -0.032 & 0.743 \\
\hline $\begin{array}{l}\text { Intact parathyroid } \\
\text { hormone (pg/ml) }\end{array}$ & -0.45 & 0.022 & 0.202 & 0.073 & 0.115 & -0.009 & 0.784 & 0.013 & -0.037 & 0.867 \\
\hline $\begin{array}{l}250 \mathrm{H} \text { vitamin D } \\
(\mathrm{ng} / \mathrm{ml})\end{array}$ & -0.56 & -0.014 & 0.453 & 0.055 & 0.084 & -0.048 & 0.911 & 0.006 & -0.034 & 0.885 \\
\hline $\begin{array}{l}\text { Crosslaps (CTX) } \\
\text { (ng/ml) }\end{array}$ & 8.03 & -0.034 & 0.850 & 0.094 & 0.035 & -0.061 & 0.584 & 0.000 & 0.024 & 0.216 \\
\hline $\begin{array}{l}\text { Alkaline phos- } \\
\text { phatase (U/I) }\end{array}$ & 0.60 & 0.006 & 0.287 & 0.247 & 0.003 & 0.014 & 0.269 & -0.099 & 0.051 & 0.120 \\
\hline Albumin (g/dl) & -0.13 & 0.017 & 0.225 & n.a. & n.a. & 0.191 & 0.011 & -0.001 & -0.027 & 0.643 \\
\hline Bilirubin (mg/dl) & -17.77 & 0.087 & 0.056 & 0.342 & 0.001 & 0.118 & 0.161 & 0.000 & -0.033 & 0.800 \\
\hline $\begin{array}{l}\text { Glutamate ox- } \\
\text { aloacetate } \\
\text { transaminase } \\
\text { (GOT, U/I) }\end{array}$ & 17.41 & -0.033 & 0.930 & 0.125 & 0.017 & -0.068 & 0.921 & 0.021 & -0.001 & 0.330 \\
\hline $\begin{array}{l}\text { Glutamic pyruvic } \\
\text { transaminase } \\
\text { (GPT, U/I) }\end{array}$ & -0.03 & -0.031 & 0.811 & -0.066 & 0.865 & -0.064 & 0.797 & 0.064 & 0.020 & 0.219 \\
\hline $\begin{array}{l}\text { Gamma glutamyl } \\
\text { transpeptidase } \\
\text { (GGT, U/I) }\end{array}$ & -0.10 & 0.099 & 0.045 & 0.070 & 0.774 & 0.072 & 0.708 & -0.172 & 0.048 & 0.123 \\
\hline $\begin{array}{l}\text { Partial throm- } \\
\text { boplastin time } \\
\text { (s) }\end{array}$ & -0.08 & -0.014 & 0.450 & 0.094 & 0.041 & -0.045 & 0.757 & 0.017 & 0.001 & 0.321 \\
\hline $\begin{array}{l}\text { International } \\
\text { normalized ratio }\end{array}$ & 1.64 & -0.009 & 0.397 & 0.228 & 0.003 & 0.040 & 0.123 & -0.001 & 0.149 & 0.020 \\
\hline Creatinine (mg/dl) & 35.89 & -0.022 & 0.568 & 0.014 & 0.159 & 0.028 & 0.122 & 0.000 & -0.033 & 0.865 \\
\hline Child-Pugh score & 6.18 & -0.001 & 0.331 & 0.667 & $<0.001$ & 0.089 & 0.056 & n.a. & n.a. & n.a. \\
\hline $\begin{array}{l}\text { Model of end } \\
\text { stage liver dis- } \\
\text { ease (MELD) } \\
\text { score }\end{array}$ & 5.95 & 0.124 & 0.027 & 0.578 & $<0.001$ & 0.278 & 0.011 & n.a. & n.a. & n.a. \\
\hline \multicolumn{11}{|c|}{$\begin{array}{l}\text { Beta reflects the regression coefficient and adjusted } R^{2} \text { the coefficient of determination (adjusted on the number of predictors) } \\
\text { In addition, albumin and adjusted calcium were included in covariate models. } P \text {-values lower then } 0.05 \text { and thereby significant relationships are indicated as } \\
\text { bold } \\
\text { n.a. not applicable }\end{array}$} \\
\hline
\end{tabular}

correlation with the model of end stage liver disease (MELD) score was observed and a trend for alcohol intake $(p=0.078)$. The strongest relations were found for radial $\mathrm{TbSp}$ and $\mathrm{TbN}$ at both the radius and tibia (Tables 1 and 2).

Fig. 1 demonstrates the relationship between sclerostin and parameters of trabecular microarchitecture.

Multivariate analysis demonstrated that the addition of albumin or adjusted calcium significantly enhanced the $\mathrm{R}^{2}$ value of sclerostin, especially for trabecular microarchitecture (Table 2). Albumin and adjusted calcium were not confounders and showed no correlation with microarchitecture without sclerostin (data not shown). Remarkably, in the controls, sclerostin showed hardly any correlation with bone microarchitecture, especially not at the weight-bearing tibia.

\section{Discussion}

This study assessed the quality of sclerostin to explain bone microarchitecture in hepatic cirrhosis. We observed slightly lower sclerostin levels compared to controls. To date, a single previous study [7] has observed increased levels; however, neither BTMs, 
Table 2 Linear regression analysis for sclerostin with areal bone mineral density and trabecular and cortical microarchitecture

\begin{tabular}{|c|c|c|c|c|c|c|c|c|c|c|}
\hline & $\begin{array}{l}\text { Beta co- } \\
\text { efficient } \\
\text { patients }\end{array}$ & $\begin{array}{l}\text { Adjusted } \\
\mathrm{R}^{2} \text { pa- } \\
\text { tients }\end{array}$ & $\begin{array}{l}p \text {-value } \\
\text { patients }\end{array}$ & $\begin{array}{l}\text { Adjusted } \mathrm{R}^{2} \\
\text { (incl. albumin) } \\
\text { patients }\end{array}$ & $\begin{array}{l}p \text {-value } \\
\text { albumin } \\
\text { patients }\end{array}$ & $\begin{array}{l}\text { Adjusted } \mathrm{R}^{2} \text { (incl. } \\
\text { adjusted calcium) } \\
\text { patients }\end{array}$ & $\begin{array}{l}p \text {-value } \\
\text { adjusted } \\
\text { calcium } \\
\text { patients }\end{array}$ & $\begin{array}{l}\text { Beta co- } \\
\text { efficient } \\
\text { controls }\end{array}$ & $\begin{array}{l}\text { Adjusted } \\
\mathrm{R}^{2} \text { con- } \\
\text { trols }\end{array}$ & $\begin{array}{l}p \text {-value } \\
\text { controls }\end{array}$ \\
\hline $\begin{array}{l}\text { Lumbar spine } \\
\text { BMD (L1-4) }\end{array}$ & 85.72 & 0.055 & 0.105 & 0.132 & 0.064 & 0.120 & 0.082 & 0.001 & 0.012 & 0.255 \\
\hline $\begin{array}{l}\text { T-score lumbar } \\
\text { spine }\end{array}$ & 8.90 & 0.038 & 0.145 & 0.156 & 0.031 & 0.086 & 0.119 & 0.008 & 0.044 & 0.138 \\
\hline Total hip BMD & 107.52 & 0.120 & 0.030 & 0.136 & 0.222 & 0.163 & 0.120 & 0.000 & -0.001 & 0.332 \\
\hline T-score hip & 13.42 & 0.093 & 0.050 & 0.130 & 0.142 & 0.128 & 0.148 & 0.003 & -0.009 & 0.393 \\
\hline Total body BMD & 112.70 & 0.103 & 0.041 & 0.264 & 0.010 & 0.140 & 0.141 & 0.001 & 0.151 & 0.020 \\
\hline Radius BMD & 140.09 & 0.064 & 0.092 & 0.049 & 0.462 & 0.064 & 0.326 & 0.001 & 0.026 & 0.193 \\
\hline $\begin{array}{l}\text { Radius cortical } \\
\text { BMD }\left(\mathrm{mg} / \mathrm{cm}^{3}\right)\end{array}$ & 0.03 & -0.032 & 0.827 & -0.016 & 0.237 & -0.060 & 0.670 & 0.155 & -0.010 & 0.410 \\
\hline $\begin{array}{l}\text { Radius tra- } \\
\text { becular bone } \\
\text { volume fraction }\end{array}$ & 562.07 & 0.146 & 0.018 & 0.328 & 0.005 & 0.190 & 0.117 & 0.000 & 0.119 & 0.032 \\
\hline $\begin{array}{l}\text { Radius trabec- } \\
\text { ular number } \\
(1 / \mathrm{mm})\end{array}$ & 65.41 & 0.279 & 0.001 & 0.401 & 0.012 & 0.353 & 0.044 & 0.000 & -0.031 & 0.764 \\
\hline $\begin{array}{l}\text { Radius trabec- } \\
\text { ular thickness } \\
(\mathrm{mm})\end{array}$ & 120.43 & -0.033 & 0.890 & 0.005 & 0.155 & -0.067 & 0.866 & 0.000 & 0.231 & 0.004 \\
\hline $\begin{array}{l}\text { Radius trabec- } \\
\text { ular separation } \\
(\mathrm{mm})\end{array}$ & -116.84 & 0.268 & 0.001 & 0.373 & 0.021 & 0.363 & 0.026 & 0.000 & -0.003 & 0.348 \\
\hline $\begin{array}{l}\text { Radius cortical } \\
\text { thickness (mm) }\end{array}$ & 40.20 & 0.001 & 0.323 & -0.016 & 0.482 & -0.021 & 0.551 & 0.000 & -0.028 & 0.668 \\
\hline $\begin{array}{l}\text { Radius cortical } \\
\text { porosity (\%) }\end{array}$ & 2.95 & -0.018 & 0.513 & -0.004 & 0.241 & -0.053 & 0.946 & -0.001 & -0.031 & 0.738 \\
\hline $\begin{array}{l}\text { Tibia cortical } \\
\text { BMD }\left(\mathrm{mg} / \mathrm{cm}^{3}\right)\end{array}$ & -0.03 & -0.032 & 0.821 & 0.102 & 0.027 & 0.004 & 0.162 & 0.296 & 0.019 & 0.219 \\
\hline $\begin{array}{l}\text { Tibia trabecular } \\
\text { bone volume } \\
\text { fraction }\end{array}$ & 564.62 & 0.155 & 0.015 & 0.344 & 0.004 & 0.270 & 0.023 & 0.000 & 0.001 & 0.317 \\
\hline $\begin{array}{l}\text { Tibia trabecular } \\
\text { number }(1 / \mathrm{mm})\end{array}$ & 69.63 & 0.255 & 0.002 & 0.341 & 0.034 & 0.330 & 0.046 & 0.000 & -0.034 & 0.959 \\
\hline $\begin{array}{l}\text { Tibia trabecular } \\
\text { thickness }(\mathrm{mm})\end{array}$ & 694.05 & -0.004 & 0.356 & 0.064 & 0.085 & 0.016 & 0.216 & 0.000 & 0.068 & 0.084 \\
\hline $\begin{array}{l}\text { Tibia trabecular } \\
\text { separation } \\
(\mathrm{mm})\end{array}$ & -182.23 & 0.188 & 0.008 & 0.348 & 0.007 & 0.325 & 0.013 & 0.000 & -0.031 & 0.756 \\
\hline $\begin{array}{l}\text { Tibia cortical } \\
\text { thickness (mm) }\end{array}$ & -8.17 & -0.032 & 0.836 & 0.178 & 0.006 & 0.124 & 0.018 & 0.001 & 0.012 & 0.253 \\
\hline $\begin{array}{l}\text { Tibia cortical } \\
\text { porosity (\%) }\end{array}$ & 1.86 & -0.003 & 0.350 & -0.004 & 0.331 & -0.037 & 0.916 & -0.007 & -0.018 & 0.487 \\
\hline
\end{tabular}

aBMD nor microarchitecture were assessed. Therefore, in our patients, aBMD could be lower due to advanced age. Moreover, we investigated Caucasians, whereas Rhee et al. [7] examined Koreans. Furthermore, most of their patients had viral hepatitis, whereas more than $50 \%$ of our patients had ALD. In a study on patients with primary biliary cholangitis (PBC), local expression of sclerostin in the bile ducts was reported, especially in early stages of the disease but declined in advanced disease stages [13]. Therefore, we assume that in our patients only a minor fraction of serum sclerostin is derived from hepatic production. Finally, within the characterization and validation of the ELISA used in our study we could show that it uniquely detects sclerostin molecules containing the LRP5/6 interaction site and therefore assumed to have bioactive function. As it is not completely understood which sclerostin molecules circulate (monomers vs. dimers [14], intact vs. fragments [15]), it is even more important to further characterize binding sites of utilized antibodies and therefore specify the detected analyte.

Within the technical validation of specificity, accuracy, intra-assay precision, limit of detection, lower 

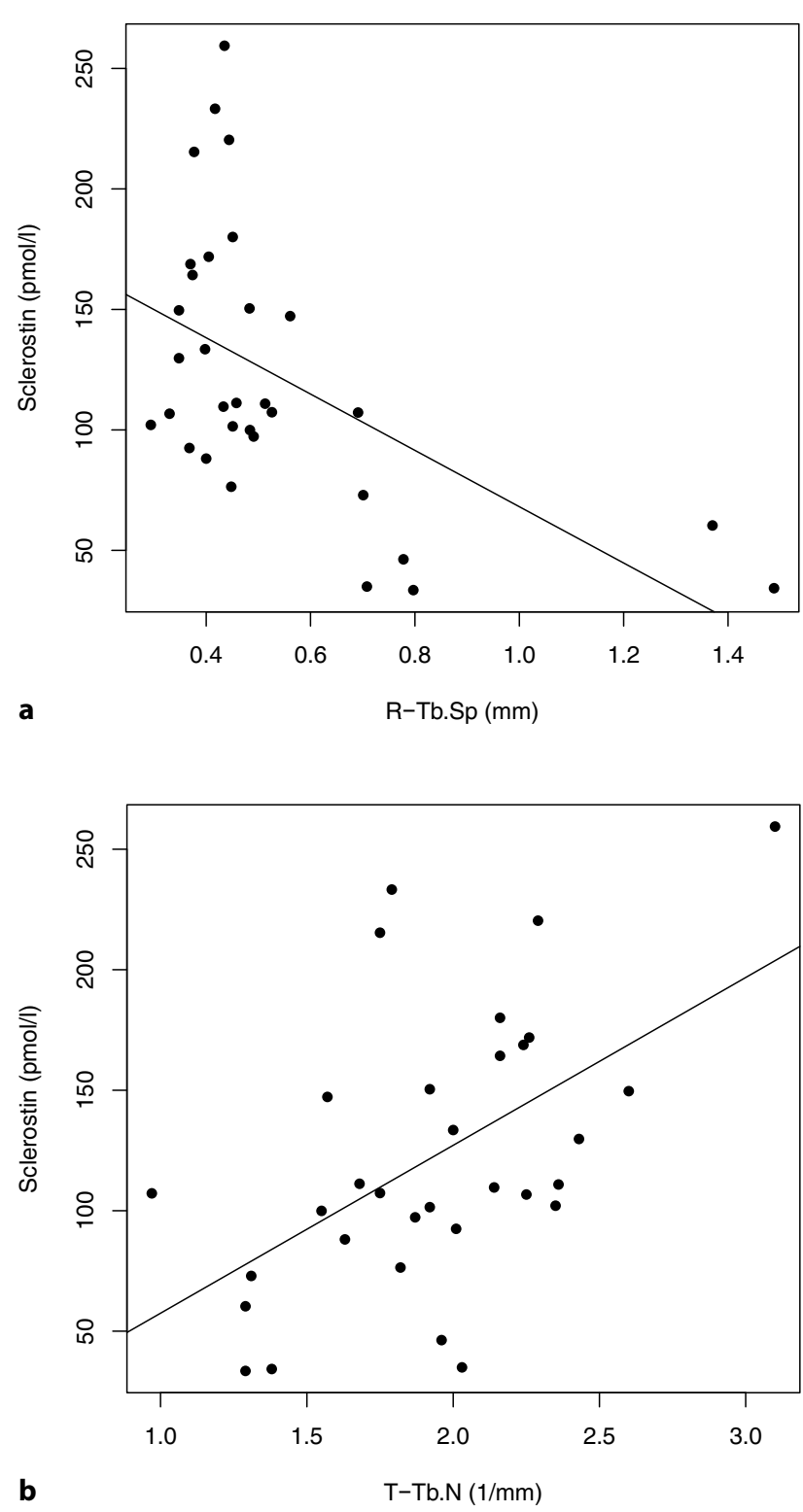

Fig. 1 Panel a: the regression analysis demonstrates a significant $(p=0.001)$ inverse correlation between serum sclerostin and TbSp at the radius. Panel $b$ reflects a significant $(p=0.002)$ direct correlation between serum sclerostin and $\mathrm{TbN}$ at the tibia

limit of quantification and sample parallelism, we could show that the novel ELISA completely meets all quality standards comparable with other sclerostin assays on the market [16] but in contrast to those assays, the novel ELISA used in this study has clearly defined binding sites.

Sclerostin correlated with the MELD score, but neither the Child-Pugh nor the MELD scores improved the predictive value of sclerostin (data not shown). Albumin improved the $\mathrm{R}^{2}$ value of sclerostin for microarchitecture. These findings emphasize the presence of a liver-bone axis in terms of a strong relation between liver function and bone health. Especially albumin (synthetic function) together with sclerostin explained deranged bone structure in our patients. Similarly, in a large population-based outpatient study, lower albumin was independently associated with osteoporosis [17]. Rhee et al. [7] found higher sclerostin levels in advanced disease states and suggested lower hepatic clearance and altered concentrations of sex hormones to explain these findings. Similarly, patients with advanced ALD had higher sclerostin levels than in less pronounced states [10]. In contrast, those of our patients with ALD had significantly lower sclerostin levels, probably as alcohol promotes osteocyte apoptosis [18]. Moreover, maybe more sclerostin fragments are circulating and detected with their assay but not with our ELISA. Adjusted calcium improved $\mathrm{R}^{2}$ especially for trabecular microarchitecture, probably due to the correction for low albumin. Moreover, adjusted calcium was decreased in patients in whom we also observed deranged microarchitecture [3]; however, albumin and adjusted calcium did not correlate with sclerostin. Rhee et al. [7] did not test for relations with BTMs. Our patients' sclerostin levels correlated with aBMD and microarchitecture. Similarly, in older men serum sclerostin [19] is related to microarchitecture and higher fracture risk. Lower serum sclerostin [11] and lower femoral sclerostin expression correlated with impaired trabecular microarchitecture in patients with hip fractures [20].

Sclerostin is produced predominantly by osteocytes. As low sclerostin expression is related to low bone volume and number of osteocytes per volume [21], lower trabecular bone volume and/or increased osteocyte apoptosis could explain the lower sclerostin levels in our patients. Alcoholism promotes osteocyte apoptosis, as demonstrated in a rat model [22]. In addition, in bone samples of patients with hepatic cirrhosis of various etiologies, a decreased number of osteocytes was reported [23]; however, bone histomorphometry was not available in our patients and therefore, further studies are required to confirm our assumption. In contrast, sclerostin levels could be decreased due to a rescue mechanism. A study on male idiopathic osteoporosis reported that lower sclerostin expression could reflect an autoregulatory promotion of bone formation [24]. As osteoblast activity is reduced in hepatic cirrhosis [25], this mechanism could act as an attempt to preserve osteogenesis. The relatively small sample size is a limitation of our study. The possibility exists that in a higher number of subjects some differences in serum sclerostin concentrations could become significant. In conclusion, serum sclerostin levels reflect deterioration of bone microarchitecture and osteocyte function in patients with hepatic cirrhosis. Patients with ALD had significantly lower sclerostin levels compared to other etiologies.

Funding Open access funding provided by Medical University of Vienna. 
Conflict of interest J. Wallwitz is an employee at The Antibody Lab GmbH. Support in the form of research material was provided but no additional role in the study design, data collection and analysis, decision to publish, or preparation of the manuscript. C. Muschitz received speaker fees from Amgen, Novartis, Servier, Eli Lilly, Nycomed Pharma/ Takeda, Kwizda Pharma, Boehringer Ingelheim, Actavis and Daiichi Sankyo. He also received educational grants/research support from the Austrian Society for Bone and Mineral Research, Roche Austria, Eli Lilly Austria, Eli Lilly International and Amgen Austria. He has nothing to disclose concerning this manuscript. P. Pietschmann received research support and/or fees from Amgen $\mathrm{GmbH}$, Biomedica $\mathrm{GmbH}$, DePuySynthes, Eli Lilly GmbH, Fresenius Kabi Austria, Meda Pharma/Mylan GmbH, Shire Austria GmbH, TAmiRNA GmbH and UCB Pharma. He has nothing to disclose concerning this manuscript. H. Resch received speaker fees from Amgen, Novartis, Servier, Eli Lilly, Nycomed Pharma/Takeda. He also received educational grants/research support from the Austrian Society for Bone and Mineral Research, Roche Austria, Eli Lilly Austria, Eli Lilly International and Amgen Austria. He has nothing to disclose concerning this manuscript. R. Wakolbinger, G. Bodlaj, X. Feichtinger, J.E. Schanda and A. Baierl declare that they have no competing interests.

Open Access This article is licensed under a Creative Commons Attribution 4.0 International License, which permits use, sharing, adaptation, distribution and reproduction in any medium or format, as long as you give appropriate credit to the original author(s) and the source, provide a link to the Creative Commons licence, and indicate if changes were made. The images or other third party material in this article are included in the article's Creative Commons licence, unless indicated otherwise in a credit line to the material. If material is not included in the article's Creative Commons licence and your intended use is not permitted by statutory regulation or exceeds the permitted use, you will need to obtain permission directly from the copyright holder. To view a copy of this licence, visit http://creativecommons.org/licenses/by/4.0/.

\section{References}

1. Santos LAA, Lima TB, Augusti L, et al. Handgrip strength as a predictor of bone mineral density in outpatients with cirrhosis. J Gastroenterol Hepatol. 2016;31:229-34.https:// doi.org/10.1111/jgh.13062.

2. Lupoli R, Di Minno A, Spadarella G, et al. The risk of osteoporosis in patients withliver cirrhosis: a meta-analysis of literature studies. Clin Endocrinol (Oxf). 2016;84:30-8. https://doi.org/10.1111/cen.12780.

3. Wakolbinger R, Muschitz C, Scheriau G, et al. Bone microarchitecture and bone turnover in hepatic cirrhosis. Osteoporos Int. 2019; https://doi.org/10.1007/s00198019-04870-6.

4. Culafić D, Djonic D, Culafic-Vojinovic V, et al. Evidence of degraded BMD and geometry at the proximal femora in male patients with alcoholic liver cirrhosis. Osteoporos Int. 2015;26:253-9. https://doi.org/10.1007/s00198-0142849-4.

5. Burghardt AJ, Issever AS, SchwartzAV, et al. High-resolution peripheral quantitative computed tomographic imaging of cortical and trabecular bone microarchitecture in patients with type 2 diabetes mellitus. J Clin Endocrinol Metab. 2010;95:5045-55. https://doi.org/10.1210/jc.2010-0226.

6. Compton JT, Lee FY. A review of osteocyte function and the emerging importance of sclerostin. J Bone Joint Surg
Am. 2014;96(19):1659-68. https://doi.org/10.2106/JBJS. M.01096.

7. Rhee Y, Kim WJ, Han KJ, et al. Effect of liver dysfunction on circulating sclerostin. J Bone Miner Metab. 2013;32:545-9. https://doi.org/10.1007/s00774-013-0524-z.

8. Ardawi MSM, RouziAA, Al-SibianiSA, etal. High serum sclerostin predicts the occurrence of osteoporotic fractures in postmenopausalwomen: the center of excellencefor osteoporosisresearch study. JBone Miner Res. 2012;27:2592-602. https://doi.org/10.1002/jbmr.1718.

9. García-Martín A, Rozas-Moreno P, Reyes-García R, et al. Circulating levels of sclerostin are increased in patients with type 2 diabetes mellitus. J Clin Endocrinol Metab. 2012;97:234-41. https://doi.org/10.1210/jc.2011-2186.

10. González-Reimers E, Martín-González C, de la Vega-Prieto MJ, et al. Serum sclerostin in alcoholics: a pilot study. AlcoholAlcohol. 2013;48:278-82. https://doi.org/10.1093/ alcalc/ags 136.

11. Dovjak P, Dorfer S, Föger-Samwald U, et al. Serum levels of sclerostin and dickkopf-1: effects of age, gender and fracture status. Gerontology. 2014;60:493-501. https://doi. org/10.1159/000358303.

12. Drake MT, Fenske JS, Blocki FA, et al. Validation of a novel, rapid, high precision sclerostin assay not confounded by sclerostin fragments. Bone. 2018;111:36-43. https://doi. org/10.1016/j.bone.2018.03.013.

13. Guañabens N, Ruiz-Gaspà S, Gifre L, et al. Sclerostin expression in bile ducts of patients with chronic cholestasis may influence the bone disease in primary biliary cirrhosis. J Bone Miner Res. 2016;31:1725-33. https://doi.org/10. $1002 / j b m r .2845$.

14. Hernandez P, Whitty C, Wardale JR, Henson FMD. New insights into the location and form of sclerostin. Biochem Biophys Res Commun. 2014;446:1108-13. https://doi.org/ 10.1016/j.bbrc.2014.03.079.

15. DurosierC, vanLieropA, FerrariS, etal. Association of circulating sclerostin with bone mineral mass, microstructure, and turnover biochemical markers in healthy elderly men and women. J Clin Endocrinol Metab. 2013;98:3873-83. https://doi.org/10.1210/jc.2013-2113.

16. Piec I, Washbourne C, Tang J, et al. How accurate is your sclerostin measurement? Comparison between three commercially available sclerostin ELISA kits. Calcif Tissue Int. 2016;98:546-55. https://doi.org/10.1007/s00223-0150105-3.

17. AfshinniaF, WongKK, Sundaram B, etal. Hypoalbuminemia and osteoporosis: reappraisal of a controversy. J Clin Endocrinol Metab. 2016;101:167-75. https://doi.org/10. 1210/jc.2015-3212.

18. Maurel DB, Boisseau N, Benhamou CL, Jaffre C. Alcohol and bone: review of dose effects and mechanisms. Osteoporos Int. 2012;23:1-16. https://doi.org/10.1007/s00198-0111787-7.

19. Szulc P, Boutroy S, Vilayphiou N, et al. Correlates of bone microarchitectural parameters and serum sclerostin levels in men: the STRAMBO study. J Bone Miner Res. 2013;28:1760-70. https://doi.org/10.1002/jbmr.1888.

20. Föger-Samwald U, Patsch JM, Schamall D, et al. Molecular evidence of osteoblast dysfunction in elderly men with osteoporotic hip fractures. Exp Gerontol. 2014;57:114-21. https://doi.org/10.1016/j.exger.2014.05.014.

21. Föger-Samwald U, Vekszler G, Hörz-Schuch E, et al. Molecular mechanisms of osteoporotic hip fractures in elderly women. Exp Gerontol. 2016;73:49-58. https://doi.org/10. 1016/j.exger.2015.11.012.

22. Maurel DB, Benaitreau D, Jaffré C, et al. Effect of the alcohol consumption on osteocyte cell processes: a molecular 
imaging study. J Cell Mol Med. 2014;18:1680-93. https:// doi.org/10.1111/jcmm.12113.

23. Bihari C, Lal D, Thakur M, et al. Suboptimal level of boneforming cells in advanced cirrhosis are associated with hepatic osteodystrophy. Hepatol Commun. 2018;2:1095-110. https://doi.org/10.1002/hep4.1234.

24. Patsch JM, Kohler T, Berzlanovich A, et al. Trabecular bone microstructure and local gene expression in iliac crest biopsies of men with idiopathic osteoporosis. J Bone Miner Res. 2011;26:1584-92. https://doi.org/10.1002/jbmr.344.

25. Pietschmann P, Resch H, Müller C, et al. Decreased serum osteocalcin levels in patients with liver cirrhosis. Bone Miner. 1990;8:103-8.

Publisher's Note Springer Nature remains neutral with regard to jurisdictional claims in published maps and institutional affiliations. 